JPASDEV

Journal of Public Administration

and Sociology of Development

Vol.1, No.1, Juli 2020

\title{
Impelementasi Kebijakan Penanggulangan HIV/AIDS pada Dinas Kesehatan Kabupaten Melawi
}

\author{
Endang Susilawati ${ }^{1}$ \\ 1. Dinas Kesehatan Kabupaten Melawi \\ Korespondensi Penulis : susilawatiendang985@gmail.com
}

\begin{abstract}
Policy implementation of HIV/AIDS Countermeasures in the Melawi Regency Health Office. The aim of this research is to describe and analyze the process of implementing HIVIAIDS policy in Melawi Regency in terms of communication, resources, disposition and bureacucratic structure. The research subjects include the Head of Health Office, Secretary of Health Office, the Division and Section Heads, Technical staff managing HIVIAIDS, Hospital director including the VCT Team and Private Hospitals, 11 Regency Public Health Center Heads, VCT Staff at the Nanga Pinoh Public Health Center, community Leaders, PLWHA and Key Population.

Research results indicate that the implementation of HIV/AIDS countermeasures in Melawi Regency has not been as expected. It is observed from the communication stage that has not been well established in the response to the aforementioned illness, the inadequate resources of supporing infrastructure and funds that have not been focused. Human Resources have not been trained. Data collection, program managers, and the role disposisition of officers are not optimal. The bureaucracy structure has not been prepared properly, including SOP and SPM. This is observed from the different perceptions of the officers managing the HIV/AIDS program. The application system has not been well apprehended due to the absence of technical staff and PLHIV/key population unwilling to volunteer to be treated.
\end{abstract}

Key words : The Implementation Policy, HIV/AIDS Countermeasures. 


\section{Pendahuluan}

Salah satu penyakit yang kini dirasa sebagai permasalahan yang cukup mendapat perhatian dari Pemerintah adalah penyakit HIV/AIDS. HIV/AIDS merupakan isu kesehatan yang cukup sensitif untuk dibicarakan,merupakan penyakit yang mematikan, yang penderitanya diwajibkan meminum obat seumur hidupnya. Hal ini berkaitan dengan sifat yang unik dari penyakit ini. Selain kasusnya yang seperti fenomena gunung es, yaitu persebaran kasus HIV/AIDS yang tidak dapat diprediksi pada fase awal. Maka kasus-kasus yang terlihat adalah ketika telah terinfeksi dan telah dinyatakan positif terkena HIV/ AIDS. Stigma dan diskriminasi juga banyak dialami oleh penderita dan keluarganya. Tingginya stigma masyarakat terhadap penderita HIV/AIDS menyebabkan banyak perlakuan diskriminatif baik dalam hal pekerjaan, perawatan, pengobatan, pendidikan maupun dalam hal lainnya.

Masalah HIV/AIDS sekarang ini sudah lama menjadi perhatian dunia. Penyakit ini menjadi masalah kesehatan yang perlu mendapat penanganan serius. Hal ini dikarenakan penanganan penyakit ini masih belum ada obatnya serta tingkat laju perkembangan kasusnya secara global yang terus mengalami peningkatan. Penyakit menular Seksual terus menjadi ancaman bagi penduduk didunia. Pemberantasan penyakit menular yang merupakan bagian dari pembangunan kesehatan menjadi perhatian setiap negara. Salah satu penyakit menular yang menjadi fokus perhatian adalah HIV dan AIDS. HIV dan AIDS merupakan salah satu jenis penyakit menular seksual akibat Perilaku Hubungan Seksual (PHS) yang berisiko.

Menurut Direktur Jenderal Pencegahan dan Pengendalian Penyakit (P2P) Kemenkes RI, dr. Anung Sugihantono, M.Kes (pada 1 Desember 2019), mengatakan Sejak pertama kali dilaporkan di Indonesia tahun 1987 sampai bulan Maret tahun 2019, kasus HIV AIDS yang telah dilaporkan adalah $461(89,7 \%)$ dari 514 kabupaten/kota di seluruh Indonesia. Data ini menunjukkan bahwa kasus HIV AIDS cenderung meluas keberadaannya di Indonesia. Data terakhir, sampai Maret 2019, jumlah kumulatif kasus HIV yang dilaporkan adalah sebanyak 338.363, yaitu 58,7\% dari estimasi ODHA tahun 2016 sebanyak 640.443.

Kabupaten Melawi merupakan salah satu kabupaten yang berada di provinsi Kalimantan Barat. Salah satu Kabupaten yang sedang berkembang dan tak terlepas pula dari permasalahan kesehatan masyarakat, khususnya menyangkut masalah sosial HIV dan AIDS. Penyebaran HIV dan AIDS di Kabupaten Melawi dapat dilihat dari berbagai Faktor-faktor risiko itu cukup mudah diamati di masyarakat seperti sexs bebas dan penggunaan narkoba jarum suntik (Napsun). Menurut data yang didapatkan dari Dinas Kesehatan Kabupaten Melawi tercatat dari data pendererita HIV pada tahun 2017 sebanyak 2 orang, 2018 sebanyak 4 orang 
dan 2019 sebanyak 7 orang, tahun 2020 sebanyak 16 orang.

Implementasi Pemerintah Daerah dalam bentuk merancang dan mengkoordinasikan aksi bersama seluruh elemen masyarakat, yang konkret dan rutin dalam rangka pencegahan dan penanganan HIV/AIDS. Semua tertuang di dalam kebijakan Perpres Nomor 75 Tahun 2006 yang memuat aturan dimana Pemerintah Provinsi dan Kabupaten/Kota wajib membentuk Komisi Penanggulangan AIDS (KPA) di wilayahnya serta Permendagri Nomor 20 Tahun 2007 tentang Pedoman Pembentukan KPA di tingkat Provinsi dan Kabupaten/Kota, dan Peraturan Menteri Kesehatan RI Nomor 21 tahun 2013 tentang Penanggulangan HIV/AIDS

Penanggulangan HIV/AIDS di Kabupaten Melawi, dengan menghimpun, menggerakkan, menyediakan dan memanfaatkan sumberdaya berasal dari Pusat, Daerah, Masyarakat, dan bantuan luar negeri secara efektif dan efisien.Untuk kegiatan Penanggulangan HIV dan AIDS di Kabupaten Melawi, melakukan koordinasi terhadap pelaksanaan tugas dan fungsi masing-masing bidang, lembaga yang tergabung dalam keanggotaan Komisi Penanggulangan AIDS (KPA) Kabupaten Melawi.

Penelitian ini akan mendalami fakta dibalik fenomena tersebut, sehingga diharapkan penulis dapat mengungkap akar masalah atau factor-faktor tertentu, sehingga implementasi penanggulangan HIV/AIDS di Kabupaten Melawi semakin terarah dan mantap ke depannya.
Oleh karena itu penulis tertarik untuk meneliti tentang implementasi kebijakan penanggulangan HIV/AIDS pada Dinas Kesehatan Kabupaten Melawi.

Dari latar belakang masalah sebagaimana disampaikan di atas; masalah penelitian ini berbicara pada:

a. Masalah HIV/AIDS di Kalbar sudah masuk kategori sangat rentan dan rawan, Menurutnya, dari awal berdiri sampai dengan akhir tahun 2018, KPA Kalbar telah menangani sebanyak 7.114 jiwa yang positif mengidap HIV, serta 1.414 jiwa yang positif AIDS. Termasuk Kabupaten Melawi tahun 2020 ini HIV berjumlah 16 orang bila dibandingkan tahun 2019 berjumlah 7 orang, sementara AIDS tahun 2020 berjumlah 20 orang. Dengan demikian penulis merasa prihatin dan terpanggil untuk menganalisa permasalahan HIV/AIDS begitu melonjak kenaikannya. Selain menangani HIV/AIDS, kita juga kedatangan masalah baru yang juga marak, seperti Corona Virustahun 2019 (Covid 19),TBC dan kanker. Jumlahnya kalau kita kolaborasikan sangat-sangat memprihatinkan.

b. Pasien HIV/AIDS maupun keluarga pasien yang anggota keluarganya mengalami persoalan besar terkadang tidak siap untuk menerima pasien HIV/AIDS ini, ketidak-siapan ini disebabkan oleh rasa takut dan sebagian karena malu, yang banyak masyarakat menganggap pasien ini sebagai aib keluarga. Data tentang pasien HIV/AIDS sangat sulit 
mendapatkan data mereka, sebagai akibat dari pasien merasa takut dan malu untuk mengunjungi Rumah Sakit/VCT maupun mengunjungi dokter dan perawat yang ada untuk memeriksakan dirinya, atau dengan kesadaran sendiri.

c. Masih lemahnya motivasi kerja tenaga teknis untuk secara kontinyu melaksanakan perawatan kepada pasien HIV/AIDS, sehingga menyebabkan faktor penanggulangan HIV/AIDS yang tidak berjalan baik, sehinggga mempengaruhi keberhasilan implementasi kebijakan penanggulangan. Untuk melaksanakan perawatan maupun penanggulangan ada faktor yang harus dilakukan antara lain pendekatan awal kepada pasien HIV/AIDS dan keluarga pasien yang tidak berproses; dugaan proses penyembuhan yang rumit dan panjang sehingga menakutkan pasien dan keluarga; tujuan kebijakan oleh pemerintah yang tidak terfahami dengan baik oleh pasien HIV/AIDS dan keluarga pasien, sehingga program belum berjalan sesuai kapasitas lembaga; dan juga komitmen pasien HIV/AIDS beserta keluarga yang tidak stabil, karena dilandasi rasa takut dan malu sehingga menyulitkan petugas dalam proses perawatan atau penyembuhan.
Menurut Edwards III dalam Agustino (2006:115) ada empat variable dalam kebijakan public yaitu komunikasi (communications), sumberdaya (resources), sikap (dispositions atau attitudes) dan struktur birokrasi (bureucratic structure).

Keempat factor tersebut harus dilaksanakan secara simultan karena antara satu dengan yang lainnya memiliki hubungan yang erat. Edward III menggunakan empat indicator dari kebijakan itu sebagai faktor yang mempengaruhi keberhasilan suatu implementasi kebijakan.

\section{MetodePenelitian}

Penelitian ini dilakukan dengan menggunakan pendekatan kualitatif dengan jenis penelitian eksploratif. Pendekatan kualitatif menurut Moleong (2011, 6) bahwa: "Penelitian kualitatif adalah penelitian yang bermaksud untuk memahami fenomena tentang apa yang dialami oleh subjek penelitian misalnya prilaku, persepsi, motivasi, tindakan dan lain-lain secara holistik dan dengan cara deskripsi dalam bentuk kata-kata dan bahasa, pada suatu konteks khusus yang alamiah dan dengan memanfaatkan berbagai metode alamiah."

Jenis penelitian eksploratif menurut Arikunto $(2006,7)$ penelitian eksploratif adalah penelitian yang bertujuan untuk menggalir secara luas tentang sebab-sebab atau hal-hal yang mempengaruhi terjadinya sesuatu. Metode penelitian eksploratif adalah penelitian yang bertujuan untuk 
memetakan suatu objek secara relatif mendalam atau dengan kata lain penelitian eksploratif adalah penelitian yang dilakukan untuk mencari sebab atau hal-hal yang mempengaruhi terjadinya sesuatu dan dipakai manakala kita belum mengetahui secara persis dan spesifik mengenai objek penelitian.

Lokasi yang menjadi tempat penelitian dalam penelitian ini, adalah Kabupaten Melawi seperti ; Dinas Kesehatan, RSUD, Rumah Sakit Swasta, Puskesmas se Kabupaten Melawi dan Lokalisasi serta Petugas lapangan/dokter/ perawat dan tokoh masyarakat

Adapun objek penelitian ini adalah Implementasi kebijakan penanggulangan HIV/AIDS di Kabupaten Melawi, guna memperoleh gambaran tentang objek yang akan di teliti, dan penelitian ini memerlukan Subjek penelitian sebagai sumber informasi/imforman . Menurut Meleong (2000;97) adapun penentuan informan dalam penelitian ini dilakukan secara purposive, yaitu tehnik untuk menentukan informan berdasarkan tujuan atau keperluan yang ditetapkan peneliti itu sendiri dengan pertimbangan tertentu. adalah :

Informan dalam penelitian ini

a. Kepala Dinas Kesehatan Kabupaten Melawi beserta pejabat structural dan tenaga tehnis.

b. Direktur Rumah sakit Umum Daerah beserta pejabat structural dan tenaga tehnis serta pengelola Voluntary Counseling And Testing (VCT) di RUSD Kabupaten Melawi

c. Direktur Rumah Sakit Kasih Bunda Jaya beserta pejabat structural dan tenaga tehnis

d. Direktur Rumah Sakit Citra Husada beserta pejabat structural dan tenaga tehnis

e. Kepala Puskesmas Kecamatan beserta pejabat structural dan tenaga tehnis yang masing-masing

f. Tokoh Masyarakat orang

g. ODHA di Lokalisasi 5 orang

Adapun teknik yang digunakan adalah sebagai berikut:

\section{a. Observasi}

b. Wawancara

c. Dokumentasi

Menurut Sugiyono (2014, 117)

"Uji Keabsahan data merupakan derajat ketetapan antara data yang terjadi pada objek penelitian dengan data yang dapat dilaporkan oleh peneliti. Dengan demikian data yang valid adalah data "yang tidak berbeda" antara data yang dilaporkan peneliti dengan data yang sesungguhnya terjadi pada objek penelitian".

Uji keabsahan data dalam penelitian kualitatif ditekankan pada aspek validitas dan realibilitas. Dalam penelitian ini, yang diuji validitasnya adalah data. Validitas adalah derajat ketepatan antara data yang terjadi pada objek penelitian yang dapat dilaporkan oleh peneliti. Data hasil penelitian dikatakan valid apabila data yang dilaporkan oleh peneliti dengan data yang sesungguhnya terjadi pada objek penelitian tidak berbeda. Realibilitas berkenaan dengan derajat konsistensi dan stabilitas data. Data dikatakan reliabel apabila dua atau lebih peneliti dalam objek yang sama menghasilkan data yang 
sama. Teknik triangulasi digunakan untuk pengecekan data dari berbagai sumber dengan berbagai cara dan berbagai waktu.

Penelitian ini menggunakan pendekatan penelitian kualitatif. Dalam pendekatan kualitatif peneliti bermaksud untuk memahami fenomena-fenomena apa saja yang terjadi di lapangan dengan cara mendeskripsikan dalam bentuk katakata dan bahasa pada suatu konteks khusus yang alamiah dan dengan memanfaatkan metode ilmiah. Dalam penelitian kualitatif, data diperoleh dari berbagai sumber dengan menggunakan teknik penggumpulan data yang bermacam-macam dan dilakukan terusmenerus sampai datanya jenuh.Menurut Miles dan Hiberman (dalam Sugiyono 2014, 183) terdapat aktivitas dalam analisis data, yang mana aktivitas ini saling berhubungan dalam menganalisa data yang didapat. Jadi pada penelitian ini, dalam menganalisa data menggunakan reduksi data, penyajian data, serta verifikasi data (penyimpulan)

\section{Hasil Penelitian Dan Pembahasan}

\section{Faktor Komunikasi}

Faktor

mempengaruhi

implementasi suatu kebijakan adalah komunikasi. Menurut Edward dalam Budi Winarno (2007:174) komunikasi berkenaan dengan bagaimana kebijakan dikomunikasikan kepada organisasi dan atau publik dan sikap serta tanggapan dari pra pihak yang terlibat. Sedangkan pengertian komunikasi itu sendiri merupakan proses penyampaian informasi dari komunikator kepada komunikan. Komunikasi sangat menentukan keberhasilan pencapaian tujuan dari implementasi kebijakan penanggulangan HIV/AIDS di Kabupaten Melawi.

Dalam implementasi berkaitan erat dengan pelaksanaan program yang direncanakan. Oleh karena itu gambaran pekerjaan yang jelas serta cara pelaksanaannya juga tersusun dengan baik. Program adalah penjabaran dari suatu rencana, dalam hal ini program merupakan bagian dari perencanaan dan sering pula diartikan bahwa program adalah kerangka dasar dari pelaksanaan suatu kegiatan. Westra (1989:236) mengatakan bahwa "program adalah rumusan yang memuat gambaran pekerjaan yang akan dilaksanakan beserta petunjuk cara-cara pelaksanaanya". Siagian (dalam Westra 1989:124) mengatakan bahwa "penyusunan program adalah penjabaran suatu rencana yang telah ditetapkan sedemikian rupa sehingga program kerja itu memiliki ciriciri operasional tertentu" Menurut Winarno (2007:144) Implementasi dipandang secara luas mempunyai makna pelaksanaan undang-undang dimana berbagai aktor, organisasi, prosedur dan teknik bekerja bersama-sama menjalankan kebijakan dalam upaya untuk meraih tujuan-tujuan kebijakan. Nugroho (2003:158) mengemukakan bahwa: "implementasi kebijakan pada prinsipnya adalah cara agar sebuah kebijakan dapat mencapai tujuannya. Dari pendapat ahli ini yang perlu ditekankan adalah bahwa tahap 
implementasi kebijakan tidak akan dimulai sebelum tujuan-tujuan dan sasaran-sasaran ditetapkan diidentifikasikan oleh keputusan yang bijaksana.

Kebijakan program penanggulangan HIV/AIDS pada Dinas Kesehatan Kabupaten Melawi yang arahnya lebih banyak kepada pencegahan penyebaran HIV/AIDS dan perawatan ODHA sehingga ODHA bisa sehat dan dapat kembali bersama masyarakat biasa. Jadi stikma ODHA yang dianggap sebagai aib masyarakat dapat di hilangkan jauh-jauh sangkaan tersebut. Wawancara peneliti (bulan Mey 2020 ) kepada responden yang tokoh masyarakat Nanga Pinoh Kabupaten Melawi semuanya mengajak untuk menerima pasien HIV/AIDS itu dengan baik-baik, hentikan stikma yang menganggap mereka sebagai aib masyarakat. Selanjutnya peneliti berkomunikasi dengan Tokoh Masyarakat bagaimana tanggapan mereka terhadap pasien HIV/ AIDS dan sebagai upaya berkoornasi dan bekerja sama dalam penanggulangan HIV/AIDS di Kabupaten Melawi.

Berdasarkan buku Pedoman Nasional Manajemen Program Penanggulangan HIV/AIDSdi jelaskan tujuan umum program penanggulangan HIV/AIDS sektor kesehatan adalah mengendalikan penularan HIV/AIDS, meningkatkan kualitas hidup ODHA serta menurunkan tingkat kesakitan dan kematian akibat HIV/AIDS. Berdasarkan hasil wawancara dan telaah dokumen yang diamatidi Dinas Kesehatan Kabupaten Melawi tidak ditemukan buku
Pedoman Nasional Manajemen Program HIV/AIDS, namun yang ada hanya buku konselor dan buku tentang VCT, buku PMTCT, dan buku tentang LKB (Layanan Komprehensif Berkesinambungan) yang merekadapatkan sewaktu mengikuti pelatihan. Mereka bekerja hanya berdasarkan buku pelatihan yang didapatkan itu. Sesuai dengan buku pedoman nasional manajemen program HIV/AIDS hadirnya buku ini memberikan pedoman dalam menjalankan program penanggulangan HIV/AIDS pada berbagai tingkat administrative yang pada akhirnya mampu meminimalisir permasalahan dan tantangan yang selama ini dihadapi secara lebih strategis. Manfaat buku ini disamping bermanfaat bagi program manajer dan tenaga Teknik program, buku ini juga bermanfaat bagi para pengambil keputusan baik pihak eksekutif maupun legislatif, para donor, Lembaga swadaya masyarakat, atau organisasi non pemerintah yang dibidang pengendalian

Penulis mewawancarai Ibu Rita Yuliani, SKM. Pengelola Program HIV/ AIDS pada Bidang Pengendalian dan Pencegahan Penyakit Dinas Kesehatan Kabupaten Melawi (Mei 2020 ) menurut anda bagaimana masalah penanggulangan HIV/AIDS di Kabupaten Melawi, responden menjawab "masalah HIV dan AIDS belum dianggap masalah prioritas baik oleh sektor kesehatan maupun sektor pembangunan yang terkait ; dukungan 
politik yang belum memadai terhadap program promosi kondom dan pengurangan dampak buruk padahal kedua program ini merupakan program pokok upaya penanggulangan HIV/AIDS, dan masih belum maksimalnya penyebaran dan akses informasi layanan kesehatan dan ketersediaan adanya layanan VCT, ARV bagi penderita dan orang beresiko tinggi terinfeksi HIV dan AIDS"

\section{Faktor Sumberdaya}

Faktor kedua yang mempengaruhi keberhasilan implementasi suatu kebijakan adalah sumber daya. Sumber daya merupakan hal penting lainnya dalam mengimplementasikan kebijakan, menurut Goerge C. Edward III (dalam Agustino, 2008:151-152). Indikator sumber daya terdiri dari beberapa elemen, yaitu staff, wewenang, informasi dan fasilitas. Dalam implementasi kebijakan penanggulangan HIV/AIDS di Kabupaten Melawi berhungan dengan informasi sudah diberikan secara lengkap, namun system kerja tenaga teknis staf dari Dinas Kesehatan belum terlalu jelas, walaupun jumlah staf cukup memadai, sehingga implementasi kebijakan ini belumlah berjalan dengan baik.

Berkenaan dengan hal tersebut komunikasi antar pihak, yaitu antara Dinas Kesehatan Kabupaten Melawi mutlak dilakukan koordinasi untuk memperkuat implementasi dan juga mendapat dukungan dalam pengadaan sumber daya implementasi. Wujud sumber daya yang sangat diperlukan Dinas Kesehatan Kabupaten Melawi adalah sumberdaya manusia, sumber daya keuangan yang dapat diarahkan untuk melengkapi fasilitas, biaya operasional dan lain-lain.

Faktor kultural budaya yaitu Faktor pelaku (aktor) menjadi salah satu penentu dalam implementasi kebijakan HIV/AIDS. Karena HIV/AIDS merupakan masalah yang tidak hanya menyangkut epidemi, tetapi juga terkait dengan faktor sosial, ekonomi, politik, dan budaya. Keaktifan para aktor dalam implementasi kebijakan menjadi penentu utama, bahkan ditemukan bukti bahwa meski suatu daerah belum memiliki kebijakan penanggulangan HIV/AIDS, tapi karena terdapat pelaku-pelaku yang aktif dan punya perhatian terhadap masalah HIV/AIDS, intervensi program dapat berjalan efisien. Dalam konteks budaya Indonesia, faktor ketokohan menjadi aspek penentu keberhasilan program . Jenis-jenis respons pencegahan yang ada di daerah antara lain tes dan konseling HIV, PPIA, PMTS dengan pendistribusian kondom, program LASS, dan terapi metadon untuk kelompok penasun, serta berbagai program komunikasi, informasi dan edukasi (KIE) yang menyasar kepada populasi umum khususnya remaja, ibu-ibu rumah tangga, dan laki-laki berisiko rendah masih terlihat kurang diminati masyarakat. Aspek psikososial dari ODHA belum memperoleh perhatian karena keterbatasan kapasitas fasilitas pelayanan kesehatan untuk menyediakan layanan sesuai standar.

Padahal ketersediaan dukungan psikososial dalam perawatan ARV 
merupakan unsur penting kaitannya dengan tingkat drop out dan kepatuhan berobat. Meskipun sudah menjalankan pendekatan Layanan Komprehensif Berkesinambungan (LKB) dengan mengembangkan integrasi layanan mulai dari koordinasi pemangku kepentingan kunci HIV/AIDS lintas-sektor dengan melibatkan peran aktif masyarakat. Ini merupakan upaya mengintegrasikan layanan HIV/AIDS yang didelegasikan sampai ke tingkat layanan primer mulai dari diagnosis, tes HIV (Voluntary Counselling Test/VCT dan Providerinitiated Counselling and Testing/PICT), link to care, dan pendampingan kepatuhan bagi ODHA yang terapi ARV. Mitigasi dampak merupakan respons paling minimal dalam penanggulangan HIV/AIDS karena respons mitigasi terindikasi belum berjalan dan tidak terkoordinasi. Ini mengindikasikan bahwa pemahaman SKPD anggota KPAD terkait continuum of care PDP ODHA masih terbatas-selain ketakjelasan peran SKPD sebagai anggota KPAD yang memiliki peran dan tanggung jawab untuk ambil bagian dalam penanggulangan HIV/AIDS. Di samping itu, dukungan terhadap ODHA lebih banyak dilakukan oleh LSM dan tokoh masyarakat yang dalam praktiknya juga banyak tidak berkoordinasi dengan dinas terkait.

\section{Faktor Disposisi}

Faktor ketiga yang mempengaruhi keberhasilan implementasi suatu kebijakan adalah factor Disposisi. Disposisi adalah karakteristik yang dimiliki oleh implementor. Disposisi menentukan keberhasilan sebuah implementasi kebijakan. Apabila implementor memiliki disposisi yang baik maka dia akan dapat menjalankan kebijakan dengan baik seperti apa yang diinginkan oleh pembuat kebijakan. Disposisi memegang salah satu peran penting dalam keberhasilan sebuah implementasi kebijakan. Hal ini dikarenakan dalam menjalankan tugasnya, seseorang harus paham dan memiliki pandangan yang baik terkait dengan kebijakan tersebut.

$\begin{array}{ccc}\text { Dapat } & \text { dipahami } & \text { bahwa } \\ \text { implementasi } & \text { kebijakan } & \text { dalam } \\ \text { menanggulangi } & \text { HIV/AIDS } & \text { masih }\end{array}$
perlu perbaikan yang serius, karena Dinas Kesehatan belum terpadunya programprogram antara jajarannya, termasuk ke Rumah Sakit Umum Daerah dan VCTnya, Puskesmas juga, baik dalam perencanaan dan pembiayaan dalam upaya penanggulangan HIV/AIDS. Begitu juga dengan populasi kunci dalam Per Educator yang dilatih tidak mempunyai tingkat pendidikan yang baik, sehingga tingkat pemahaman dan kemampuan menerima bimbingan tentang HIV/AIDS relative sulit. Program pemerintah tentang pemakaian kondom dalam seks beresiko tinggi belum dapat dilakukan secara baik, sehingga temuan orang yang terinfeksi HIV/ AIDS tetap diketemukan, dengan kata lain control program ini agak kesulitan pengawasannya, karena yang paling diharapkan adalah kesadaran diri dari populasi kunci untuk selalu menjaga diri. Sumber daya manusia (SDM) memainkan peran signifikan dalam 
sistem kesehatan dan penanggulangan HIV/ AIDS. Maka, diperlukan integrasi Sumberdaya AIDS dalam sistem kesehatan untuk memperbaiki kesenjangan ketersediaan tenaga AIDS. Penyediaan Sumber daya manusia kesehatan ini, kini mendapatkan tantangan dari desentralisasi yang memberikan kewenangan daerah untuk menyediakan tenaga kesehatan,karena respons terhadap tren epidemi di suatu wilayah tidak dapat dilepaskan dari konteks kebijakan setempat.

Dalam konteks desentralisasi, Peraturan Pemerintah (PP) Nomor 38 Tahun 2007 tentang Pembagian Urusan Pemerintahan antara Pemerintah, Pemerintah Daerah Provinsi, dan Pemerintah Daerah Kabupaten/Kota telah mengamanatkan pembagian kewenangan antara pemerintah kabupaten/kota terkait pengelolaan, penempatan, pendayagunaan, peningkatan kapasitas, registrasi, pembinaan, dan pengawasan Sumber Daya Manusia kesehatan. Salah satu cara untuk melihat integrasi SDM AIDS dalam sistem kesehatan ialah dengan mengkaji apakah pengadaan sampai pembinaan dan pengawasan SDM AIDS sudah mengikuti sistem SDM kesehatan pada umumnya. Namun demikian ada kecenderungan kesamaan pola dalam respons pencegahan HIV/AIDS, khususnya terkait dengan model intervensi dan target standar penjangkauan dan pendampingan.

\section{Faktor Struktur Birokrasi}

Menurut Edward III (dalam Agustino, 2008:153-154), yang mempengaruhi keberhasilan implementasi kebijakan publik adalah struktur birokrasi. Walaupun sumber daya untuk melaksanakan suatu kebijakan tersedia, atau para pelaksana kebijakan mengetahui apa yang seharusnya dilakukan, dan mempunyai keinginan untuk melaksanakan suatu kebijakan, kemungkinan kebijakan tersebut tidak dapat dilaksanakan atau direalisasikan karena terdapat kelemahan dalam struktur birokrasi. Kebijakan yang begitu kompleks menuntut adanya kerjasama banyak orang, ketika stuktur birokrasi tidak kondusif pada kebijakan yang tersedia, maka hal ini akan menyebabkan sumberdaya-sumberdaya menjadi tidak efektif dan menghambat jalannya kebijakan.

Pendanaan penanggulangan HIV/ AIDS yang bersumber dari Anggaran Pendapatan dan Belanja Daerah (APBD) melalui Satuan Kerja Pemerintah Daerah (SKPD) terkait masih terbatas. Upaya penanggulangan HIV \& AIDS ke dalam sistem kesehatan nasional memperlihatkan banyaknya produk kebijakan tidak berkorelasi langsung dengan efektivitas upaya penanggulangan HIV/AIDS di Kabupaten Melawi. Perangkat hukum lebih merupakan upaya pemenuhan aspek legalitas dan prosedural sebagai bukti adanya itikad dari pemerintah dalam merespons epidemi AIDS, tetapi komitmen secara praktis dalam pendanaan masih sangat kecil. Kebijakan penanggulangan 
HIV/AIDS menunjukkan, konteks dualisasi kebijakan dan peraturan di tingkat nasional terkait penanggulangan HIV/AIDS masih jauh dari harapan. Dalam SRAD, misalnya, upaya penanggulangan AIDS masih belum menjadi prioritas. Padahal kontekstualisasi SRAD yang berbasis pada data epidemi lokal dan penganggaran dari sumber pembiayaan lokal (APBD) maupun kerja sama sektor swasta lain berkontribusi pada kemandirian dalam pencegahan HIV/AIDS yang strategis, serta efektivitas program sesuai dengan status epidemi HIV/AIDS dan konteks persoalan di daerah masing-masing, baik provinsi maupun kabupaten/kota.

\section{Kebijakan Yang Harus Dilakukan dalam Upaya Penanggulangan HIV/AIDS di Kabupaten Melawi Secara teoretis}

Secara teoritis pendekatan horizontal dalam bidang kesehatan (seperti penanggulangan HIV \& AIDS) dengan pengandaian adanya integrasi lintas sektor dan lintas program dalam merespons problem epidemi bisa menjadi visi pembangunan kesehatan ke depan yang komprehensif dan berkesinambungan,sehingga layanan yang diberikan lebih efektif dan efisien harus dilakukan antara lain;

Pertama, di samping kebijakan yang progresif dan ketersediaan sumber daya (manusia, biaya, teknologi, dan pengetahuan) yang pada galibnya masih bersifat vertikal, faktor penentu keberhasilan intervensi kesehatan dalam penanggulangan HIV/AIDS adalah rasa kepemilikan dan komitmen dari berbagai pihak terhadap program. LKB dirancang untuk semakin mendekatkan layanan hingga ke tingkat komunitas dengan membangun keterlibatan stakeholders lintas sektor.

Tantangan yang cukup besar: ketersediaan sumber daya kesehatan yang memenuhi kualitas, sumber pembiayaan yang jelas, dan komitmen dari para pemangku kepentingan. Rasa kepemilikan terhadap LKB dapat dilihat dari sejauh mana setiap pihak berkoordinasi dan memberikan kontribusi secara nyata untuk mewujudkan layanan yang berkesinambungan dan komprehensif, misalnya dalam hal cost sharing proses intervensi yang diberikan oleh Dinas Kesehatan dan Komisi Penanggulangan AIDS (KPA).

Kedua, masalah jaminan kualitas layanan dari tenaga kesehatan dan tenaga non kesehatan menjadi krusial dalam rangka memberikan layanan yang efektif dan berkualitas.

Komitmen para pemangku kepentingan untuk memberikan layanan yang responsif dan sensitif terhadap kebutuhan pasien merupakan prasyarat yang penting. Kualitas ini berbanding lurus dengan kapasitas dari semua pemangku kepentingan. Kapasitas dan pengetahuan yang baik akan berdampak langsung pada peningkatan kualitas layanan.

Ketiga, indikasi efektivitas dari integrasi program LKB dalam sistem kesehatan umum adalah meningkatnya kepuasan pasien dalam beberapa aspek layanan, seperti tingkat kecepatan 
layanan, kapabilitas tenaga kesehatan dalam memberikan layanan, perlakuan yang lebih ramah dari tenaga kesehatan, dan terjaganya kerahasiaan pasien. Meningkatkan nilai tambah dari keberadaan kebijakan AIDS, terdapat beberapa faktor kunci yang perlu diperhatikan dalamproses implementasi kebijakan. Salah satunya, penting untuk menggali faktor-faktor yang menjadi pendukung dan penghalang (barrier) implementasi kebijakan.

\section{Secara praktis}

Secara praktis langkah-langkah yang harus dilakukan dalam upaya penanggulangan HIV dan AIDS di Kabupaten Melawi adalah melalui program - program terpadu baik Satuan Kerja Perangkat Daerah (KPAD, Stake Holder (WPS, LSL, PPS, Waria, IDU'S) dan Masyarakat (WPA, LSM, Perusahaan dan sebagainya ).

Dari aspek substansi hukum antara lain dengan lebih memperkuat landasan operasional terutama petunjuk teknis dan petunjuk pelaksanaan yang mengatur mulai dari perencanaan, pelaksanaan, evaluasi, monitoring , sanksi.

Dari aspek struktur/ kelembagaan antara lain meningkatkan fungsi dan tugas KPA baik secara kualitas, manegement serta kelembagaan KPA dan program pendukung berupa pendanaan/pengalokasian anggaran pada setiap SKPD terkait . Meningkatkan akses dan kualitas pelayanan kesehatan bagi ODHA dan anak dengan HIV dan AIDS/ADHA, dan kelompok yang beresiko tinggi tertular (RISTI), dan
Orang Yang Hidup dengan HIV dan AIDS/OHIDHA) . Meningkatkan keterlibatan swasta dan pelaku usaha/industri/perusahaan khususnya terhadap karyawan dan penggalangan dana, sarana dan prasarana yang mendukung program penanggulangan HIV/AIDS di lingkungannya.

Pemenuhan kebutuhan Sumber Daya Manusia dilakukan melalui pengadaan tenaga kerja multiplier, pengalihan tugas, dan penambahan jumlah staf melalui jalur reguler atau pengadaan khusus lewat tenaga honorer maupun jalur proyek. Tenaga outreach, konselor, dan manajer kasus, misalnya, dapat direkrut sebagai tenaga kesehatan melalui skema PNS atau tenaga honorer.

Memberikan kesempatan sektor non pemerintah atau masyarakat sipil yang terlatih, pemerintah turut andil mewujudkan pengakuan terhadap kesetaraan serta mengurangi stigma dan diskriminasi. Skema lain ialah mekanisme pengalihan tugas, yang meliputi perluasan tanggung jawab atas pasien HIV dari spesialis/internis ke dokter umum, pergeseran tanggung jawab beberapa layanan dari dokter kepada perawat, dan rangkap tugas perawat sebagai teknisi laboratorium sederhana (untuk menyelesaikan masalah kekurangan kapasitas laboratorium yang menghambat ekspansi pengobatan). Artinya, pengelolaan SDM AIDS dapat lebih direncanakan dengan melihat kebutuhan dan kapasitas tenaga kesehatan di suatu daerah, sehingga mutasi tenaga kesehatan terlatih tidak 
menghambat keberlanjutan layanan HIV/ AIDS

Dari aspek budaya/kultur baik petugas maupun stake holder dan masyarakat antara lain meningkatkan pemahaman masyarakat tentang HIV/AIDS dengan benar dan peran serta masyarakat dalam upaya penanggulangan HIV/AIDS. Meningkatkan keterlibatan Populasi Kunci dengan cara mengundang Lembaga Swadaya Masyarakat (LSM) peduli Hiv dan Aids dan kelompok resiko tinggi dalam perencanaan program dan menjalankan program serta evaluasi program sebagai petugas lapangan (PL), Konselor, Manager Kasus dalam Komisi Penanggulangan AIDS. Dalam pembentukan budaya/kultur dilakukan dengan cara mempengaruhi sikap dan perilaku secara terus menerus/rutin agar dapat memahami, menyikapi proses penanggulangan dan empati, sehingga diharapkan memperkecil diskriminasi terhadap ODHA.

\section{Langkah-langkah kongkrit yang dilakukan dalam upaya penanggulangan HIV dan AIDS Di Kabupaten Melawi}

Adapun langkah-langkah kongkrityang dilakukan dalam upaya penanggulangan HIV dan AIDS antara lain sebagai berikut:

a. Melaksanakan

kegiatan sosialisasitentang HIV/AIDS dari berbagai sudut pandangan ; tentang bagaimana terjadi penularannya, resiko apabila pasien terjangkit $\mathrm{HIV} /$ AIDS, Langkah-langkah perawatan pasien HIV/AIDS, cara menghindari penyakit, maupun upaya menanggulangi HIV/AIDS secara umumnya. Pelaksanaannya dengan melalui komunikasi informasi dan edukasi (KIE) baik melalui sarana langsung (penyuluhan, seminar/pelatihan, screning darah PMI) maupun tidak langsung (melalui poster/iklan/siaran radio, Televisi. layanan hot line);

b. Selalu meningkatkan koordinasi melalui pertemuan dengan stake holder secara rutin, terus menerus dan pemberdayaan ODHA dan WPA melalui kegiatan kegiatan pelatihan, advokasi; Koordinasi sangatlah diperlukan dalam upaya penanggulangan HIV/AIDS di Kabupaten Melawi. Jajaran Dinas Kesehatan Kabupaten Melawi sebaiknya kontinyu berkoordinasi dengan Rumah Sakit Umum Daerah, Rumah Sakit Swasta, Puskesmas termasuk kepada dokter dan perawat dalam berbagai aktifitas penanggulangan HIV/AIDS.

c. Buatkanprogram pencegahan penularan HIV/AIDS di lingkungan tempat kerja dengan memberikan pengetahuan, pemahaman serta perlindungan bagi karyawan/pekerja . Hal ini dimungkinkan adanya program komperhensif dari Perusahaan dalam upaya mendukung program pemerintah kota Surakarta dalam penanggulangan HIV/AIDS;

d. Dinas Kesehatan Kabupaten Melawi membuka akses pelayananKesehatan berupa(promosi, pengobatan, 
rehabilitasi) khususnya VCT/KTS, IMS, CST/PDP di tiap Puskesmas dan menjamin tersedianya Layanan Komperhensif Berkesinambungan (LKB);

e. Sebagai wujud kepedulian dari Pemeritah Kabupaten Melawi kepada pasien HIV/AIDS maupun ODHA dibentuk lembaga social ekonomi dan keagamaan bagi mereka sebagai wadah pemberdayaan dan layanan sosial bagi ODHA dengan memberikan bekal pengetahuan dan pelatihan ketrampilan dalam bidang social, budaya, keagamaan dan ekonomi.

f. Sebagai Langkah yang Positif Dinas Kesehatan Kabupaten Melawi selalu melakukan monitoring dan evaluasi terhadap KPA bila sudah terbentuk, kepada tim tehnis, dokter, perawat yang memberikan LKB sebagai dasar pembuatan kebijakan pelaksanaan secara berkala;

g. Bila dipandang perlu setelah mengevaluasi dan pengembangan kebijakan penanggulangan HIV dan AIDS melalui regulasi dalam peraturan daerah, peraturan Bupati Melawi, keputusan Bupati, terutama yang menyangkut petunjuk teknis/pelaksanaan program program, baik regulasi, penataan SDM, penganggaran/alokasi pembiayaan melalui APBD maupun partisipasi warga dan institusi swasta.

\section{Simpulan dan Rekomendasi}

\subsection{Simpulan}

Berdasarkan hasil penelitian dan pembahasan mengenai strategi implementasi kebijakan penanggulangan HIV/AIDS yang dilakukan pada Dinas Kesehatan Kabupaten Melawi. Implementasi kebijakan yang dilaksanakan Dinas Kesehatan Kabupaten Melawi dapat disimpulkan sebagai berikut ::

a. Pada factor komunikasi antar pelaksana kebijakan penanggulangan HIV/AIDS Dinas Kesehatan Kabupaten Melawi dengan kelompok sasaran telah berjalan dengan baik. Hal ini dapat dilihat dari ketiga indikator transmisi, kejelasan dan konsisten. Pada indicator transmisi komunikasi sudah berjalan baik karena informasi yang disampaikan langsung diberikan kepada sasaran kebijakan yaitu petugas pengelola program HIV/ AIDS baik di tingkat Dinas Kesehatan itu sendiri,RSUD ( VCT nya ), RS swasta dan petugas pengelola program HIV/ AIDS yang tesebar di 11 Puskesmas ( 11 Kecamatan ) se Kabupaten Melawi. Sehingga program penanggulangan HIV/AIDS tersebut bisa tersampai dengan baik kepada kelompok-kelompok resiko tinggi, komunitas-komunitasODHA, dan masyarakat. Indikator kejelasan komunikasi sudah cukup baik karena program penanggulangan HIV/AIDS tidak hanya dilakukan sosialisasi langsung namun juga sosialisasi tidak langsung yaitu dengan menggunakan berbagaimedia. Indikator konsisten 
komunikasi sudah baik karena pemberian informasimengenai penanggulangan HIV/AIDS telah dilakukan secara konsisten di Kabupaten Melawi.

b. Pada factor sumber daya pada Dinas Kesehatan Kabupaten Melawi secara keseluruhan sudah cukup baik. Namun, masih adanya kekurangan dana dan motivasi kerja sumber daya manusia di Dinas Kesehatan Kabupaten Melawi dalam melaksanakan kebijakan penanggulangan HIV/AIDS. Namun dengan komunikasi, koordinasi yang baik dengan semua pihak, maka implementasi kebijakan penanggulangan HIV/AIDS di Dinas Kesehatan Kabupaten Melawiserta dukungan faktor sarana dan prasarana sehingga program ini dapat terlaksana walaupun belum begitu maksimal.

c. Pada factor disposisi atau sikap kecenderungan pelaksana sudah terlihat sangat baik. Hal ini dikarenakan adanya dukungan dari berbagai pihak yang mendukung sepenuhnya program penanggulangan HIV/AIDS untuk mencapai Indonesia bebas HIV/AIDS tahun 2030. Para pelaksana juga telah memberikan pelayanan yang baik, sopan dan ramah, menjadi salah satu bukti bahwa tenaga pelaksanan benar-benar memiliki kemauan dan kepatuhan dalam melaksanakan program penanggulangan HIV/AIDS di Dinas Kesehatan Kabupaten Melawi.

d. Pada factor struktur birokrasi dapat dilihat dari indikator-indikator, yaitu: pertama, indikator SOP pada Dinas Kesehatan Kabupaten Melawi selaku pelaksana program belum memiliki SOP khusus. Namun, dalam memberikan layanan kepada masyarakat diserahkan kepada masing-masing stakeholder. Kedua, indikator fragmentasi telah berjalan baik karena telah sesuai dengan perandan tugas serta koordinasi antar pihak pelaksana dalam penyuluhan se tingkat dibawahnya ( sesuai jenjang yang ada ).

\subsection{Rekomendasi}

Adapun rekkomensasi yang peneliti berikan dalam implementasi Kebijakan penanggulangan HIV/AIDS Dinas Kesehatan Kabupaten Melawi adalah sebagai berikut :

a. Dalam komunikasi penulis rekomendasikan, untuk meningkatkan upaya program penanggulangan HIV/ AIDS Dinas Kesehatan Kabupaten Melawi perlu mengintensifkan peran Dinas Kesehatan Bersama jajarannya kepada Rumah Sakit Umum Daerah, Puskesmas serta ke Pemerintah Daerah dan DPRD Kabupaten Melawi.

b. Untuk meningkatkan Sumber Daya, Dinas Kesehatan Kabupaten Melawi perlu membuatStandar Operational Procedures (SOP) khusus program penanggulangan HIV/AIDSuntuk mengatur perosedur-prosedur kerja agarlebihterencana

danterperincidengan baik, serta perlu bimtek system informasi HIV/AIDS (SIHA) untuk meningkatkan 
kemampuan kerja urusan input data dan pelaporan.

c. Berkaitan dengan disposisi penulis menyarankan Dinas Kesehatan Kabupaten Melawi untuk melibatkan stakeholder terkait, baik SPKD, DPRD, LSM, Tokoh Masyarakat, Tokoh Agama maupun pihak pengusaha Swasta, serta tokoh budaya lainnya.

d. Berhubung dengan struktur birokrasi, penulis menyarankan dalam upaya penanggulangan HIV/AIDS di Kabupaten Melawi perlulah Dinas Kesehatan membuat Tim kerja (seperti KPA) dari semua tingkatan ; Dinas Kesehatan, Rumah Sakit Umum Daerah (RSUD) Rumah Sakit Swasta, VCT, Puskesmas, yang juga disusun secara Tupoksi kerjanya.

\section{Referensi}

Agustino, L. (2012). Dasar-Dasar Kebijakan Publik. Bandung: Alfabeta.

(2096). Politik dan Kebijakan Publik, Asosias iIlmu Politik Indonesia, (AIPI), Bandung

Abdul, W. S. (1990). PengantarAnalisisKebijaksanaan Negara. Jakarta: Penerbit PT. RinekaCipt

Arman, S. (2017). Metode Penelitian Kualitatif. Yogyakarta: Kepel Press

Arman, S. (2003). Bahan Kuliah Metode Penelitian, Fakultas Ilmu Sosial dan Politik Universitas Tanjungpura Pontianak
Arikunto, (2005). Publishing Co.Bache, Ian dan Matthew Flinders Multi Level Governance Oxford, USA

Arriza, B., \&Indah, K. (2011). Memahamirekonstruksikebahagia an pada Orang dengan HIV/AIDS

Anderson, J. E. (1984). Public Policy and Politics in America. California: Rooks/Cole

Badjuri, H., \&Abdulkahar, Y., Teguh, (2003).KebijakanPublik, Konsep dan Strategi. Semarang :UniversitasDiponegor o

Budi Utomo, (2015). Pencegahan HIV/AIDS Belum Optimal, Republika CO.ID

Dahlan, Alwi, dkk. (1995). Kamus Besar Bahasa Indonesia, Jakarta Balai Pustaka

Darmadi, D. dan Sukidin, (2009). AdministrasiPublik. Yogyakarta : LaksBang

PressSindo.

Donal S., V.M. dan Carl E., Van Horn, (1975). The Policy Implementation Process : Conceptual Framework, Sage Publication, Ins.

Dunn, W.N. (1985). Pengantar Analisis Kebijakan Publik, ( diterjemah oleh Samudra

Wibawa,dkk)., 2000, Gajah Mada University Press Yogyakarta.

Edwards III, George, C., (1980). Implementing Public Policy, Congressional Quarterly Press, Washington, D.C.

Grindles, M. S. (1980). Politics and Policy Implementation in the third 
JPASDEV

Journal of Public Administration

and Sociology of Development

Vol.1, No.1, Juli 2020

World. New Jersey: Princenton University Press

Hill, Michael and Peter Hupe. (2010).

Implementing Public Policy.

London: SAGE

Publications Ltd

Holsti, KJ. 1987 Metode Penelitian

Kualitatif: Aplikasi Praktis

Pembuatan Proposal dan

Laporan Penelitian. Malang:

UMM Press.

Tachjan. (2006). Implementasi Kebijakan

Publik, Asosiasi Ilmu Politik Indonesia (AIPI), Bandung

Hastuti, E. (2011). HIV dalam Keluarga,

Fakultas kedokteran Universitas Indonesia

Notoatmodjo, S. (2007). Promosi Kesehatan dan Ilmu Perilaku. Jakarta: PT. Rineka Cipta Odendal

Kementerian Kesehatan RI. (2013). Peraturan Menteri kesehatan RI Nomor 21 tahun 2013 TentangPenanggulangan HIV Dan AIDS. Jakarta

Kementerian Kesehatan RI (2012). Buku Pedoman Penerapan Layanan Komprehensif HIV -AIDS dan IMS bagi Kader. Dirjen PP \& PL, Depkes RI, Jakarta

Kementerian Kesehatan RI. (2009). KebijakandalamPenanggulangan IMS, HIV dan AIDS. Dirjen PP \& PL, Depkes RI, Jakarta

Moleong, L.J. (2017). Metode Penelitian

Kualitatif, Cetakan ke 36 Bandung PT Remaja Rusdakarya Offset.
Martoyo. (2016). Lokus \& Fokus Ilmu Administrasi Publik. Kediri : Fam Publishing

Martoyo, \& Munawar, MS, (2016). Kelembagaan Sektor Publik. Kediri:Fam Publishing

Sugiyono.(2016). Metode Penelitian, Kuantitatif, Kualitatif, dan $R \& D$, Cetakanke 23. Bandung :Alfabeta.

Sugiyono.( 2016). Metode Penelitian Administras. Bandung : Alfabeta.

Sugito. (2017). BukuAjar ; Kebijakan Publik, Fakultas Ilmu Sosial dan Politik Universitas Tanjungpura Pontianak

Silalahi,U. (2008). Faktor-Faktor yang berhubungan denganp erilaku pencegahan HIVIAIDS pada PSK di Kabupaten Bulukumba

Winarno,B.(1989). Teori Kebijakan Publik, Pusat Antar Universitas Studi Sosial, Universitas Gajah Mada, Yogyakarta.

KebijakanPublik :Teori, dan StudiKasus. Yogyakarta: Center of Academic Publishing Service (CAPS).

Widodo, J. ( 2007). Analisis Kebijakan Publik. Malang: Bayumedia Publishing.

\section{Dokumen :}

Peraturan Menteri kesehatan RI Nomor 21 tahun 2013 TentangPenanggulangan $\quad H I V$ Dan AIDS. Jakarta

Peraturan Menteri Kesehatan RI Nomor 1507/Menkes/X/2005 tentangPedomanPelayananKonse 
JPASDEV

Journal of Public Administration

and Sociology of Development

Vol.1, No.1, Juli 2020

ling dan Testing

SecaraSukarela( VoluntaryCounc

eling and Testing)

KomisiPenanggulangan AIDS Provinsi

Kalimantan Barat tahun 2010

KomisiPenanggulangan AIDS Nasional

2003, Strategi Nasional

Penanggulangan HIV/AIDS

Jakarta

Kementerian Kesehatan RI, 2013.

PedomanPelaksanaanPencegaha

$n$ Dan Pengendalian

Infeksi HIV bagiPetugasKesehatan di

PelayananKesehatan.Dirjen PP

\& PL, DepkesRI, Jakarta

Kementerian Kesehatan RI, 2012.

PedomanPenerapanLayananKom prehensif HIV-IMS

Berkesinambungan.Dirjen $P P \quad \& \quad P L$, Depkes RI, Jakarta.

Kementerian Kesehatan RI, 2013.

PedomanPelaksanaanPencegaha

$n$ Dan Pengendalian

Infeksi HIV bagiPetugasKesehatan di

PelayananKesehatan.Dirjen PP

\& PL, DepkesRI, Jakarta 